\title{
Wyrok Sądu Metropolitalnego w Katowicach (c. Sobański) z 10.07.2009 z tytułu niezdolności pozwanej do podjęcia istotnych obowiązków małżeńskich
}

Ius Matrimoniale 15 (21), 199-211

2010

Artykuł został opracowany do udostępnienia w internecie przez Muzeum Historii Polski w ramach prac podejmowanych na rzecz zapewnienia otwartego, powszechnego i trwałego dostępu do polskiego dorobku naukowego i kulturalnego. Artykuł jest umieszczony w kolekcji cyfrowej bazhum.muzhp.pl, gromadzącej zawartość polskich czasopism humanistycznych i społecznych.

Tekst jest udostępniony do wykorzystania w ramach dozwolonego użytku. 


\section{WYROK SĄDU METROPOLITALNEGO \\ W KATOWICACH (C. SOBAŃSKI) Z 10.07.2009 \\ Z TYTULU NIEZDOLNOŚCI POZWANEJ DO PODJĘCIA ISTOTNYCH OBOWIĄZKÓW MAŁŻEŃSKICH}

\section{Przebieg sprawy:}

JN oraz MM zawarli małżeństwo 28.8.1993. Ważność tego małżeństwa zaskarżył JN 13.2.2004 w Sądzie Metropolitalnym w Katowicach. „Tytuł prawny” powód ujął następująco: ,żona była i jest niezdolna do życia w małżeństwie, ja byłem niedojrzały do zawarcia małżeństwa”. Pozwana pismem z 8.3.2004 wniosła „o całkowite odrzucenie wniesionego pozwu”. Ponieważ pozwana podała jedynie ,adres do korespondencji”, a powód podał dwa różne adresy pozwanej, zwrócono się do pozwanej „o wskazanie miejsca zamieszkania”. Pozwana w piśmie z 12.3.2004 poinformowała, że miejsce jej stałego zamieszkania to W., zaś M. to "tylko miejsce czasowego pobytu, bez formalnego zameldowania. Pozwana wniosła „o zmianę właściwości miejscowej Sądu”, uzasadniając to także ,zabezpieczeniem bezstronności i obiektywności ocen Sadu". Poinformowano więc powoda, że z racji zawarcia małżeństwa właściwy jest Sąd Biskupi w K., zaś z racji zamieszkania pozwanej Sąd Biskupi w S. Powód skierował przeto skargę do Sądu Biskupiego w S., który przyjął sprawę do procesu 7.4.2004. Pozwana wezwana do Sądu Biskupiego, pismem z 15.7.2004, w którym jako miejsce zamieszkania podała nie W., lecz M., odmówiła udziału w procesie, „ponieważ Sąd Diecezji S. nie jest Sądem właściwym wg normy kan. 1673 nr 1 KPK”, a ona nie będzie „udzielać odpowiedzi Sądowi Biskupiemu Diecezji S. ani też włączać się w jakiekolwiek czynności procesowe podejmowane przez Sąd Biskupi w S.”. Wobec takiego stanowiska pozwanej powód wniósł 19.7.2004 o przekazanie procesu Sądowi Biskupiemu w K. Dnia 27.7.2004 Sąd Biskupi S. przekazał akta sprawy Sąowi Biskupiemu w K. Pozwana ponadto zaskarżyła kompetencję Sądu Biskupiego w S. w Najwyższym Trybunale 
Sygnatury Apostolskiej. Trybunał ten pismem z 24.7.2004 nakazał zawiesić postępowanie, zaś 21.10.2004 potwierdził kompetencję Sądu Biskupiego w S. ze względu na tymczasowe miejsce zamieszkania. Pismem z 28.11.2004 pozwana wniosła o ustalenie przedmiotu sporu w formie pytania, czy udowodniono nieważność małżeństwa z tytułu niezdolności stron do podjęcia istotnych obowiązków małżeńskich. Do tegoż pisma załączyła kopię decyzji Naczelnika Wydziału Spraw Obywatelskich Urzędu Miasta M. z 19.5.2004 stwierdzającej, że pozwana jest zameldowana na pobyt stały w M. Sąd Biskupi S. zasięgnął informacji u proboszcza parafii św. Katarzyny w W., który podał, że pozwana ma wprawdzie mieszkanie w W., ale przebywa w nim ,tylko sporadycznie". Oficjał Sądu Biskupiego S. przedstawił 4.10.2005 sprawę Najwyższemu Trybunałowi Sygnatury Apostolskiej z prośbą o jednoznaczną decyzję co do kompetencji. Trybunał ten zadecydował 31.5.2006, że sprawę winien prowadzić Sąd Metropolitalny w K. Dnia 3.7.2006 ukonstytuowano kolegialny skład Sądu i wysłano odpowiednie pisma do stron. Biorąc pod uwagę żądania i odpowiedzi stron (k. $1513 \S 1)$ oraz wysuwane argumenty (k. 1504 n. 2) ustalono dekretem z 3.7.2006 przedmiot sporu w formie pytania, czy udowodniono nieważność małżeństwa $\mathrm{z}$ tytułu niezdolności pozwanej do podjęcia istotnych obowiązków małżeńskich. Tegoż dnia zarządzono instrukcję dowodową. Dnia 18.7.2006 wpłynęła do Sądu faxem kopia pisma pozwanej z datą 10.7.2006, wysłanego do Sądu Biskupiego S. (a „do wiadomości” do Najwyższego Trybunału Sygnatury Apostolskiej i Sądu Biskupiego K.), w którym ,nie wyraża zgody” na prowadzenie sprawy przez Sąd Metropolitalny w Katowicach, co pozwana uzasadniła następująco: ,jako prokurator Prokuratury Rejonowej w M. nadzorowałam postepowanie karne w sprawie Kurii Metropolitalnej wKatowicach, której bezpośredniojurysdykcjipodlega SadMetropolitalny w Katowicach. Wedtug norm Kodeksu Prawa Kanonicznego Oficjat Sadu Metropolitalnego w Katowicach podlega bezpośrednio władzy Metropolity Archidiecezji Katowickiej, tym samym nie chciałabym, aby wykonywanie mojego nadzoru prokuratorskiego wywarto jakikolwiek wptyw, ograniczało władze Sadu Metropolitalnego w Katowicach, bąź tez insynuowało stronniczość tegoż Sadu względem mojej osoby”. Swoista logika tego pisma sprawiła, że pozostało ono bez odpowiedzi. Wezwania wysłane pozwanej na adres w W. wróciły z adnotacją,,adresat od kilku lat nie zamieszkuje pod wskazanym adresem", zaś wysłane na adres w M. wróciły z adnotacją, ,nie zamieszkuje pod wskazanym 
adresem od 2 lat". Dnia 4.9.2006 powód podał nowy adres pozwanej. Na kolejne wezwanie pozwana odpowiedziała, że do czasu wydania decyzji przez Najwyższy Trybunał Sygnatury Apostolskiej odmawia udziału w procesie. To stanowisko potwierdziła w piśmie z 27.3.2007. Sprawę trzeba było przeto prowadzić bez udziału pozwanej.

\section{Motywy prawne:}

Każdy człowiek ma niezbywalne prawo do zawarcia małżeństwa, chyba że prawo pozytywne dla określonych przyczyn wprowadza pewne ograniczenia. Prawo to człowiek realizuje - czyli zawiera małżeństwo - przez akt woli zwany zgodą małżeńską. Ten akt woli powoduje zaistnienie małżeństwa, jeśli jest aktem wolnym, świadomym, zgodnym $\mathrm{z}$ wewnętrznymi zamiarami nupturienta $\mathrm{i}$ wyrażonym zgodnie z prawem. Dlatego prawo kościelne określa braki zgody małżeńskiej, które mogą wynikać z niewystarczającego rozeznania, ograniczenia wolności, niezdolności fizycznej lub psychicznej do małżeństwa, niezgodnych z istotą małżeństwa zamierzeń.

Jedną z konsekwencji powyższych założeń jest kan. 1095, którzy brzmi: „Niezdolni do zawarcia małżeństwa są ci, którzy: (1) są pozbawieni wystarczającego używania rozumu; (2) mają poważny brak rozeznania oceniającego co do istotnych praw i obowiązków małżeńskich wzajemnie przekazywanych i przyjmowanych; (3) z przyczyn natury psychicznej nie są zdolni podjąc istotnych obowiązków małżeńskich".

Wspólne wszystkim trzem dyspozycjom kan. 1095 jest to, że określone w nich podstawy nieważności opierają się na podstawach natury psychicznej, zaś ci, u których takie przyczyny zachodzą, są uznani za niezdolnych do zawarcia małżeństwa. W dwóch pierwszych chodzi o psychiczne elementy samego konsensu małżeńskiego, w trzecim zaś o przedmiot tego konsensu. Czyli: w dwóch pierwszych chodzi o samą psychiczną zdolność do świadomego wyrażenia konsensu, w trzecim o zdolność do przekazania i przyjęcia tego wszystkiego, co w sposób istotny składa się na małżeństwo. W tym ostatnim przypadku rozeznanie i możność kierowania swym postępowaniem mogą nie podlegać brakom czy ograniczeniom, natomiast przejmowane i przekazywane prawa pozostają czcze, osoba jest do nich - tzn. do ich przyjęcia i wypełnienia - niezdolna z racji psychicznych. 
Kan. 1095 n. 3 opiera się na założeniu, że nikt nie może prawnie zobowiązać się do tego, czego nie potrafi wykonać. Jest to elementarna zasada prawa natury, akcentowana już w starożytnych i średniowiecznych źródłach prawa (Reg. 6 in $\mathrm{VI}^{\circ}$ ). Kan. 1095 n. 3 konstatuje niezdolność z przyczyn natury psychicznej. Przyczyn tych nie należy utożsamiać $\mathrm{z}$ chorobą psychiczna, aczkolwiek choroby takie mogą się wśród nich mieścić. Niezdolność do podjęcia istotnych obowiązków nie przekreśla zdolności do rozeznania ani w ogóle „zdolności życiowych" danej osoby.

Aplikacja kan. 1095 n. 3 wymaga przeto ustalenia, co należy rozumieć przez ,,istotne obowiazki malżeńskie” oraz jakie przyczyny uniezdalniają do ich podjęcia.

Analiza tego, co składa się na istotne obowiązki małżeńskie, musi wyjść od ujęcia istoty małżeństwa. Wspólnota małżeńska to wedle nauki Soboru Watykańskiego II , głęboka wspólnota życia i miłości” (GS 48), obejmująca aspekty zarówno fizyczne, jak i duchowe. Istota małżeństwa to „wyjście poza siebie”, transcendencja na drugiego człowieka. Przez zawarcie małżeństwa tworzy się nowa jedność, w której małżonkowie nie przestają być soba, nie rezygnują z tego, kim i czym sa, lecz integrują się w całość, obejmującą całokształt ich życia, właśnie we wspólnotę małżeńską. Zaistnienie takiej wspólnoty zakłada zdolność do wzajemnego oddania się i przyjęcia. Dzięki temu powstaje międzyosobowa jedność, w której wzajemna miłość małżonków odpowiednio się wyraża, rozwija i dojrzewa (por. GS 50). Chodzi - naucza Paweł VI - „o mitość pełna, to znaczy o tę szczególna forme przyjaźni, poprzez którq matżonkowie wielkodusznie dziela między sobq wszystko, bez niesprawiedliwych wyjatków i egoistycznych rachub" (enc. Humanae vitae 9). Kłóci się z taką miłością egoizm, szukanie siebie, tendencje do panowania i rządzenia, agresja wobec partnera. W świetle orzecznictwa kościelnego małżeństwo wymaga zdolności do oddania się drugiej osobie zarówno w sferze fizycznej jak i duchowej przy zachowaniu autonomii i godności osób; zdolności do przezwyciężania własnego egoizmu oraz do dostrzegania własnych niedostatków; krótko mówiąc: zdolności do wyjścia poza swój własny świat. Podkreślić przy tym trzeba wyłączność wspólnoty małżeńskiej, co oznacza oddanie się bez reszty i ofiarne współdziałanie dla wzajemnego dobra. Tego wszystkiego małżonkowie mają prawo wzajemnie oczekiwać, to wszystko składa się na małżeństwo i tym samym należy do jego kształtu prawnego. 
Aby Sąd mógł orzec nieważność małżeństwa, musi osiągnąć moralną pewność o istnieniu określonych prawem - w tym przypadku kan. 1095 n. 3 - podstaw nieważności. Pewność tę może czerpać wyłącznie z akt sprawy, tj. z zawartych w aktach faktów i dowodów (kan. 1608 §2). Dopuszczenie i ocena dowodów należy do sędziego. Świadków przedstawiają strony, biegłych powołuje Sąd. Od biegłych w sprawach o nieważność małżeństwa wymaga się nie tylko wiedzy specjalistycznej, lecz także znajomości i akceptacji nauki Kościoła o małżeństwie. Ocena ich opinii należy do Sądu, który weryfikuje przesłanki opinii i rozważa wnioski w całokształcie materiału dowodowego (kan. 1579 §1).

Przedmiotem procesu - i konsekwentnie wyroku - jest tylko i wyłącznie kwestia nieważności małżeństwa. Wyrok orzekający nieważność małżeństwa, także $\mathrm{z}$ powodu niezdolności osoby prawnie niezdolnej do zawarcia małżeństwa, nie ma charakteru dyskryminującego - Sąd nie wypowiada się wtedy o winie, lecz o nieistnieniu węzła małżeńskiego. W szczególności orzeczenie nieważności małżeństwa na podstawie kan. 1095 n. 3 w żaden sposób nie dotyka problemu winy, opiera się bowiem na istotnym dla aplikacji tego kanonu założeniu ,chciał, ale nie mógł”. Dotyczy to zawsze konkretnego, rozpatrywanego i orzekanego przez Sąd małżeństwa, nie ma charakteru generalnego.

\section{Stan faktyczny:}

1. Powód pisze w skardze, że jesienią 1990 r. zakochał się w pozwanej, będąc wtedy ,zagubiony, samotny, nieszczęśliwy ze względu na niepowodzenia na uczelni, brak perspektyw podjęcia pracy oraz złe stosunki z rodzicami”. Pozwana imponowała mu ,wrodzoną inteligencja, poza tym była jakaś inna". Ponieważ jednak była wobec niego „nielojalna, nieszczera oraz okrutna”, próbował kilka razy zerwać $\mathrm{z}$ nią, ale zaślepiony i zniewolony nie był w stanie tego zrobić, wydawało mu się, że nie potrafi bez niej żyć. Nie był w stanie wycofać się także wtedy, gdy na wiosnę 1993 pozwana po przebytej operacji ginekologicznej dziwnie się zachowywała. Po ślubie „od początku” odtrącała go od siebie, czuła „wstręt do seksu” - zgodne życie było możliwe pod warunkiem, że nie wymagał od niej współżycia.

Zeznając w Sądzie powód przyznaje, że mało wie o dzieciństwie i młodości pozwanej. Opowiadała mu, że „była nieszczęśliwa całe dzie- 
ciństwo, bo jej rodzice uwielbiali jej brata, a nie ja". Pozwana była jego pierwszą dziewczyną „na poważnie”. Zeznaje: „,Ja próbowałem zerwać z pozwana w czasie naszego narzeczeństwa. Pozwana często była okrutna wobec mnie. Jak byliśmy na imprezach, to pozwana całowała się z innymi mężczyznami. Ona była nielojalna. Było tak, że nie spotykaliśmy się np. dwa tygodnie, ale ja nie potrafitem oderwać się od pozwanej. Pozwana dobrze tańczyła, była ładna i inteligentna. Pozwana, jak miała przyjść do mnie, bo byliśmy umówieni, to poszła na całonocna impreze $i$ wróciła rano. Nic mi wtedy nie powiedziała, gdzie i z kim była. Pozwana przed ślubem mówiła, że jej nie zależy na ślubie ze mna. Pozwana twierdziła, że ja się do niej przyczepiłem. Ja się na pewno przyczepitem do pozwanej. Mnie się wtedy wydawało, że jakbym zostawit pozwana, to bym umart. To było wbrew rozsadkowi. Ja uważam, ze pozwana nie była we mnie zakochana" (k. 26, 7). Poślubne współżycie było „na siłę i bez miłości”, „aby współżyć pozwana się upijała”. Powód wyprowadził się z powodu ,wielkich awantur”, pozwana groziła, że w nocy mu ,poderżnie gardło”. Po miesiącu pogodzili się, ale znów doszło do awantury i ,zrezygnował ze wspólnego zamieszkania". Jednak dowiedział się, że pozwana zaszła w ciążę, więc znów postanowili ,ze sobą żyć”. Pozwana z dzieckiem zamieszkała u rodziców powoda, powód pracował „w różnych firmach na terenie Polski” i w domu był gościem. Wybudował dom w Warszawie, błagał pozwana, by zamieszkała z nim, ona nie zgodziła się. Pozwana judziła rodziców przeciw sobie. Powód przyznaje, że nadużywał alkoholu w małżeństwie, ,aby utopić smutki”. Pozwana prowokowała go, by ją uderzył. Ona ,jak wpadała w szał, to miała nieludzką się". Powód obecnie uważa, że ona ,jest albo lesbijką albo transseksualistką". Sama mówiła matce powoda, że ma więcej hormonów męskich niż żeńskich”. Jest - zeznaje powód - „niezwykle chwiejna w nastrojach”, ,zwykle jest w depresji i jest nieszczęśliwa, chorobliwie nieufna...”.

2. Wedle matki powoda, pozwana przed zaręczynami podpadła jej dziwnymi zachowaniami, ale podczas zaręczyn była uroczą dziewczyną. Po ślubie powiedziała świadkowi, że nigdy nie kochała powoda, a wyszła za mąż, by „udowodnić rodzicom”. Od powoda świadek wie, że pozwana ,idzie z nim do łóżka wtedy, jak jest pijana”, sama powiedziała świadkowi, że „do mężczyzn nic nie czuje i powód powinien to zrozumieć". Świadek uważa - i taka wedle świadka jest opinia sąsiadów z W. - że pozwana jest lesbijką. Świadek widziała powoda „z podrapaną twarzą". Pozwana - zeznaje świadek - „ma obsesję, że 
wszędzie są zarazki”, a z drugiej strony „ma wszędzie pełno brudu, ona nie sprząta w domu”, bierze lekarstwa ,na depresję i na nerwy”.

Ojciec powoda wie od powoda, że „od nocy poślubnej strony spały w osobnych pokojach”, a współżyli ze sobą, kilka razy w roku”, bo ona „nie potrzebuje mężczyzny”. Pozwana przyznała się świadkowi, że nigdy nie kochała powoda, a w kościele ,nie przysięgała, tylko mówiła to, co jej kazał mówić ksiądz”. Świadek zeznaje: „Przy dziecku pomagat pozwanej ojciec. Właściwie ojciec wszystko robit za pozwanq. Pozwana kapała dziecko. Pozwana do przesady pod pewnymi sprawami dbała o dziecko. Pozwana dziecka nie wypuszczała samego nawet na podwórko. Pozwana wszędzie dziecko prowadzi za rękę". Pozwana odmówiła zamieszkania w Ww., ,bo to niebezpieczna dzielnica”, a jak powód przyjeżdżał z Ww., to groziła, że go zabije. „Dziecko krzyczało, żeby mama nie zabijała tatusia. Powód przychodził do nas spać w obawie o życie", zeznaje świadek.

Siostra powoda nie słyszała, by pozwana go biła. Była natomiast świadkiem, jak pozwana, gdy powód przyjechał do M., ,całowała go w stopy, aby wrócił do W.”. Swiadek pomyślała wtedy, że ,„pozwana ma coś z głową". Wedle świadka pozwana „wobec dziecka miała histerię", a na żonę i matkę ,,absolutnie się nie nadawała” - „miała wszędzie w domu brud, ale ręce myła tak, że zdzierała skórę".

3. Wedle ojca pozwanej problemy w małżeństwie stron wiązały się od początku z nadużywaniem alkoholu przez powoda, który, pił ,średnio raz na tydzień”. O ,problemach w życiu seksualnym stron” powód opowiadał szczegółowo swemu ojcu. „Przez całe jedenaście lat wspólnego życia stron nic nie wskazywało na to, że ich małżeństwo się rozpadnie". W ostatnich latach wspólnego życia stron powód zaczął jeździć do jezuitów w Z., stał się mniej dostępny, a stało się to według świadka - dlatego, że powód ,popadł w rozterkę, ponieważ poznał drugą kobietę". Wedle świadka, "na rozkład małżeństwa duży wpływ mają rodzice powoda”. Bo „oni jako Ślązacy bardzo nieprzychylnie odnosili się do pozwanej, która pochodzi z Małopolski”, a powód ,jest bardzo uległy wobec rodziców".

Świadek złożył zeznania w siedzibie Sądu Biskupiego w S., do którego - z racji miejsca zamieszkania świadka - Sąd Metropolitalny zwrócił się zgodnie z k.1418. Po złożeniu zeznań świadek wystosował do Sądu Biskupiego w S. pismo (przekazane Sądowi Metropolitalnemu), w którym wnosi „,o ponowne przesłuchanie jako świadka przed właściwym Trybunałem do rozpoznania tej sprawy, czyli przed Sądem 
Metropolitalnym w Katowicach". Żądanie swe świadek uzasadnia twierdząc, że „Sąd Biskupi w S. nie jest właściwym do rozpoznania sprawy”, a udzielona „pomoc prawna nie jest zasadna”, bo odległość między Kuriami jest zbyt mała i nie tworzy przeszkody do przesłuchania świadka w Katowicach. Wedle świadka ,powaga sądu kościelnego i ranga rozpoznawanej sprawy wymaga, aby przesłuchania świadków prowadzili sędziowie właściwego Trybunału".

Wezwana do Sądu opiekunka dziecka stron odmówiła złożenia zeznań.

4. W aktach znajduje się kopia opinii sporządzonej przez Rodzinny Ośrodek Diagnostyczno-Konsultacyjny w S. 12.10.2005. W opinii tej napisano o pozwanej: „Na podstawie przeprowadzonych badań psychologicznych stwierdza się, iż pozwana jest osoba zrównoważona emocjonalnie, stabilna wewnętrznie. Posiada wysoka, zrównoważona samoocene. Ma poczucie kompetencji we wspótpracy z innymi - zarówno na płaszczyźnie społecznej jak i zawodowej. Wykonane przez niq testy wskazuja na dominacje ekstrawertywnych cech osobowości, z czym wiaże sie duze zapotrzebowanie na doptyw nowych bodźców, ruchliwość psychiczna, towarzyskość. Latwo wchodzi w relacje społeczne, w których jest komunikatywna, wrażliwa na odczucia i potrzeby innych, zdolna do nawiania głębokich więzi uczuciowych opartych na obustronnej wymianie uczuć i myśli. Posiada dobry, realistyczny kontakt z otoczeniem. W swoim myśleniu jest krytyczna, refleksyjna" (k. 38).

5. Pozwana - konsekwentnie - nie skontaktowała się z biegłąpsycholog. Biegła sporządziła przeto opinię opierając się na aktach sprawy. Biegła uważa, że pozwana „w chwili zawierania związku małżeńskiego była zdolna do podjęcia i wypełnienia istotnych obowiązków małżeńskich. Była jednak złośliwa i nie brała pod uwagę potrzeb powoda. Jej postępowanie wobec powoda było uświadomione i w pełni kontrolowane. Starała się robić mu ,na złość”. Nie chciała spełniać jego oczekiwań. Nie zastanawiała się nad tym, do czego może prowadzić jej postępowanie”. Wedle biegłej zachowania pozwanej „nie były wynikiem żadnych poważnych zaburzeń osobowości czy też choroby psychicznej”. Brak również, jednoznacznych danych na temat ewentualnych zaburzeń seksualnych występujących u pozwanej”.

O powodzie biegła napisała: ,W trakcie przeprowadzanych badań powód pozostawat w korzystnym kontakcie werbalnym, wyrównanym, zrównoważonym nastroju. Jego zachowanie było dostosowane do sytu- 
acji badawczej, był skłonny do wspótpracy z biegłymi. Wypowiadał się obszernie, rzeczowo, logicznie, spójnie i czytelnie odpowiadał na zadawane mu pytania. Byt nastawiony na otwarta prezentacje myśli i odczuć" (k. 38). Powód - po publikacji akt - podważył obiektywizm i zasadność tej opinii. Pisze: „,Niezrozumiałe pozostaje dla mnie, skad $u$ dziecka pojawiaja się tak poważne zaburzenia osobowości, skoro my z żona, jako rodzice - zdaniem biegtych - dobrze wypetniamy swoje obowiqzki i potrafimy porozumieć się w sprawie dziecka". Powód przedłożył kopię pisma RODK z 22.7.2005, w którym dla przeprowadzenia badań wyznaczono trzeci termin - i dopiero wtedy pozwana zjawiła się.

6. Zaznajomiwszy się z aktami powód wniósł „o przyjęcie nowych dowodów w sprawie". Wśród pism załączonych przez powoda znajduje się też postanowienie Sądu Okręgowego w K. z 10.9.2004 oddalające wniosek sędziów Sądu Rejonowego w M. o wyłączenie ich ze sprawy ,z powództwa małoletniego GN reprezentowanego przez matkę MM przeciw JN". Wniosek taki złożyli wszyscy sędziowie i asesorzy Sądu Rejonowego uzasadniając, że osobista znajomość z matką powoda może zrodzić wątpliwości „w kwestii obiektywizmu”. Sąd Okręgowy oddając wniosek stwierdził, że ,nie można uznać za stosunki osobiste kontaktów zawodowych sędziego z prokuratorem".

Ponadto powód wniósł o przesłuchanie dwojga świadków oraz o zasięgnięcie kolejnej opinii biegłego.

7. „Była szwagierka pozwanej” uważała ojca pozwanej za ideał, natomiast jej matka to „osoba bardzo męcząca i nieufna”, wedle której „wszyscy są źli”. „Jedyne, co stawiało pozwaną na nogi, to był jej tata”, zeznaje świadek. „Nie potrafiła okazywać uczuć”, wedle świadka pozwana i jej brat tak byli wychowani. Świadek nie wie, jak układało się współżycie seksualne stron. Świadek zeznaje: „,W mieszkaniu $w W$. byt zawsze straszny bałagan. Ja pamiętam, że jak pozwana wyparzała smoczki dla dziecka, to one leżaty w śmierdzqcej wodzie z kozuchem. Jak powód miat przyjechać, to przychodzili rodzice pozwanej i sprzatali. Pozwanej się nie chciało sprzatać $i$ nie miała takiego nawyku. Jak ja przychodziłam do pozwanej, to też zawsze sprzatałam, aby było gdzieś usiaść i z czego się napić. ... Pozwana nie miała sity $i$ chęci się dzieckiem zajmować. Jej jedynq radość życia przynosiła praca. Ona o sprawach, które się troczyly w pracy, opowiadała z miłościa i pasja. Ona tak o dziecku i o swoim mężu nie opowiadała. W pracy pozwana spetniała się najbardziej. ... Pozwana często myje sobie ręce. 
Ona zawsze uważała, że wszystko musi być higieniczne. Ona wpadała w skrajność. Bo wokót niej w domu było petno brudu. Pozwana wiecznie była smutna i apatyczna, a z drugiej strony ojciec mówił do niej, aby znowu nie szalała. Ja nie wiem, o co chodziło" (k. 149-150).

8. Ks. SM, dysponuje jedynie informacjami przekazanymi przez powoda. , Jego otwartość w rozmowach powodowata petny szacunek dla rozmówcy, bo mężczyźnie nie jest łatwo mówić o swoich doznaniach czy przeżyciach", ocenia świadek. Z punktu widzenia tytułu sprawy znaczące są następujące stwierdzenia świadka: „Pozwana jest dziwna osoba, bo kiedy dowiedziała się, że powód wnióst pozew do sqadu biskupiego nachalnie wydzwaniała do nas (Dom Rekolekcyjny) oskarżajac męża o różne niestworzone sprawy, a nawet obiecywata, że sama pragnie przeżyć C.D, co tylko byto robieniem tzw. atmosfery. Odczuwato sie caty wachlarz emocji od pozytywnych treści po groźby. Odnosiłem wrażenie, że sa to reakcje przynajmniej histeryczne. Z relacji i rozmów $z$ powodem odnosiłem wrażenie, że pozwana ma cechy transseksualisty” (k. 145). Wypowiedź świadka znajduje potwierdzenie i naświetlenie w pismach pozwanej. Do Sądu Biskupiego w S. pozwana napisała 28.11.2004: „Powód w swojej skardze poruszył w sposób jednoznaczny swoje psychiczne rozterki oraz walke ze złymi duchami oraz swoje medytacje w Zakonie (...) w Z. Muszę stwierdzić, że pod wpływem tych medytacji mój maż postanowit się rozwieść, aby uwolnić się od złego ducha, którego upatrzył w mojej osobie i doszedt do wniosku, że tylko uniewaznienie naszego matżeństwa pozwoli mu uwolnić się od złych duchów”. Tekst ten to reakcja pozwanej na następujący fragment skargi powoda: „Dodatkowo uważam, że żona jest opętana lub zniewolona przez złego ducha. Jej typowym zachowaniem jest rozszyfrowywanie złych stron czy lęków, po to, aby w te czułe miejsca uderzyć lub kimś manipulować. Upewniłem się o tym $w$ trakcie ćwiczeń duchowych przy regułach rozeznawania duchów. Przyjątem wtedy do wiadomości, że żona jest moim nieprzyjacielem i zaczałem ja tak traktować. Ciagle muszę być gotowy na atak, nigdy nie moge okazywać słabości. Ku mojemu zdziwieniu nasze stosunki wtedy się poprawity. Zauważytem, że żona gardzi ludźmi o dobrych intencjach, ale słabymi, podziwia natomiast silnych cyników”. Pozwana podaje w piśmie z 28.11.2004, że ,swoje zastrzeżenia do złego wpływu na męża ze strony Zakonu (...)" wyraziła „w piśmie do Przeora Zakonu”, które pozostało bez odpowiedzi. Pozwana załączyła kopię tego pisma: , Wniosek o przerwanie dalszych medytacji duchowych przez męża MM oraz 
skierowanie $w / w$ na badania psychologiczno-psychiatryczne $w$ ramach działań Zakonu”. Pozwana zarzuca, że powód „, w wyniku wieloletnich medytacji duchowych $w$ Waszym Zakonie przeszedt zasadnicza i bardzo groźna przemiane duchowa, gdyż stat się bardzo agresywnym i niebezpiecznym osobnikiem". Indoktrynacja ojca duchownego - pisze pozwana do „Ojca Przeora” - zmieniła psychikę jej męża, co jest tym groźniejsze, że on wcześniej ,przechodził różne załamania psychiczne na tle alkoholowym, a nawet leczył się psychiatrycznie, co sam przyznaje w pozwie rozwodowym”, co może „mieć groźne konsekwencje dla bezpieczeństwa wielu ludzi, którzy podróżują samolotami" (nb: w pozwie rozwodowym, którego kopię załączyła pozwana, nie ma wzmianki o leczeniu psychiatrycznym powoda). Pozwana jest - jak pisze - „,przerażona i zaniepokojona” medytacjami i oczekuje „od Ojca Przeora Zakonu odpowiedzi w przedmiotowej sprawie, a szczególnie o środkach zaradczych, które wpłyną na odmianę stanu duchowego i psychicznego" powoda.

9. Sąd zasięgnął opinii drugiej biegłej. Pozwana pozostawiła bez odpowiedzi zaproszenie do badania, biegła była przeto zmuszona oprzeć swą odpowiedź na pytania Sądu jedynie na badaniu powoda i na aktach sprawy. Biegła uważa, że ,dane zgromadzone w procesie - mimo braku obecności pozwanej - pozwalają ocenić zdolność MM w chwili zawierania małżeństwa do podjęcia i wypełnienia istotnych obowiązków małżeńskich". Referowany materiał dowodowy prowadzi biegłą do następującego wniosku: „Całość zachowań pozwanej odzwierciedla bardzo niski, tj. najniższy poziom rozwoju osobowości człowieka dorostego”. Osoby o takim - ,integracji pierwotnej” - poziomie „zazwyczaj sprawnie i szybko działaja, są egocentryczne, nie są zainteresowane potrzebami i prawami innych". Biegła pisze: „Pozwana posiadajac niedojrzata osobowość nie była zdolna do wielkodusznej i ofiarnej mitości, do podjęcia troski o powoda, darzenia go szacunkiem, nie byta otwarta na jego potrzeby i dażenia, nie była zdolna do nawiqzania z nim relacji bliskości - ani fizycznej, ani psychicznej. Swojq aktywność życiowq skoncentrowała generalnie na realizowaniu zadań zawodowych. Cechy niedojrzatej osobowości posiadała pozwana już przed ślubem. Już wówczas była osobq nerwowa, zażywała środki uspokajajace, nawiqzywała bez skrepowania bliskie kontakty z innymi mężczyznami (całowała się z nimi) w czasie, gdy spotykata sie z powodem. Brakowato jej zatem empatii, lekceważyta powoda" (k. 169). Podsumowując swą 15-stronicową opinię biegła pisze, 
że ,pozwana w chwili zawierania małżeństwa posiadała nieprawidłową - niedojrzałą - osobowość uniezdalniającą do budowania wspólnoty życia i miłości”.

10. Orzeczenie Sądu winno opierać się na dowodach i na faktach (k. 1608 §2). Pewność konieczną do orzekania sędzia może czerpać wyłącznie z akt sprawy, ale zarazem ma obowiązek uwzględnić wszystko, co znajduje się w aktach i może być przydatne dla wyświetlenia prawdy. Są to przede wszystkim dowody (oświadczenia stron, zeznania świadków, opinie biegłych, dokumenty), ale także fakty procesowe (, actitata in causa" - Clem 5,11,2.), zwłaszcza wnoszone skargi i zarzuty, sposób korzystania z uprawnień.

Oceniając sprawę Sąd nie może nie zwrócić uwagi na wysiłki pozwanej zmierzające do uniemożliwienia przeprowadzenia procesu przez wykazanie braku kompetencji sądów. Kompetencję Sądu Metropolitalnego zakwestionowała twierdząc, że miejsce jej stałego zamieszkania to W., ona jest parafianka parafii w W., a M. to tylko miejsce jej czasowego pobytu (pismo z 12.3.2004). Podając adres m. zaznaczyła, że jest on „do korespondencji”. Natomiast w piśmie z 24.5.2004 wykazuje, że jej stałe miejsce zamieszkania to M., przy czym we wniosku o decyzję Urzędu Miasta twierdzi, że mieszka pod tym adresem od siedmiu lat. Sprzeczne informacje pozwanej sprawiły, że w sprawę zaangażowano trzy sądy oraz Najwyższy Trybunał Sygnatury Apostolskiej.

Kolejny fakt procesowy to insynuacje pozwanej czy to pod adresem audytora Sądu (zarzucając mu pomoc „w przygotowaniu pozwu", dlatego, że udzielał - zresztą również pozwanej - informacji co do procedury) czy to pod adresem Sądu Metropolitalnego sugerując stronniczość Sądu dlatego, że pozwana ,jako prokurator Prokuratury Rejonowej w M.” nadzorowała ,postępowanie karne w sprawie Kurii Metropolitalnej w Katowicach, której bezpośredniej jurysdykcji podlega Sąd Metropolitalny w Katowicach”. Niezależnie od tego, że Sąd nie podlega ,jurysdykcji Kurii”, a także od tego, że trudno zorientować się, co pozwana miała na myśli pisząc o ,postępowaniu karnym przeciw Kurii”, nie sposób dostrzec, jak wykonywanie przez pozwaną „nadzoru prokuratorskiego” mogło „ograniczać władzę Sądu Metropolitalnego w Katowicach”, czy też mogło „wywierać jakikolwiek wpływ” lub ,insynuować stronność (sic!) tegoż Sądu” względem pozwanej. 
Zamiast wyłożyć wobec Sądu swe stanowisko merytoryczne i wskazać argumenty przeciw tezie powództwa, pozwana podejmuje się dużych wysiłków dla przeszkodzenia czy zgoła uniemożliwienia przeprowadzenia procesu. W taką też postawę wpisują się interwencje pozwanej u ,przeora” i prowincjała i (telefonicznie) w domu Zakonu w Z.

10. W świetle faktów procesowych trzeba zgodzić się z opinią pierwszej biegłej, że postępowanie pozwanej wobec powoda było - i jest - uświadomione i w pełni kontrolowane. Ale te fakty dowodzą też dużej zawistności pozwanej. O jej skali świadczy ,wydzwanianie” do domu rekolekcyjnego z oskarżeniami przeciw powodowi i jej pismo z 23.8.2004 „do przeora”. Za tym „uświadomionym i kontrolowanym postępowaniem" stoi osobowość scharakteryzowana przez drugą biegła. Sąd przyjmuje tę charakterystykę jako wystarczająco uzasadnioną. Szereg zarzutów podniesionych pod adresem pozwanej to dedukcja lub ocena zeznających, jednak całość materiału dowodowego nagromadzonego w aktach sprawy tworzy spójny obraz osobowości i świadczy, że oddanie się drugiej osobie i przyjęcie jej na wspólnotę całego życia przekraczało możliwości osobowościowe pozwanej.

Taki stan sprawy pozwala Sądowi uzyskać moralną pewność o osobowościowo uwarunkowanej niezdolności pozwanej do podjęcia istotnych obowiązków małżeńskich. Tak więc Sąd odpowiada twierdząco na pytanie procesowe i orzeka, że udowodniono nieważność małżeństwa.

Wyrok, aby był wykonalny, wymaga zatwierdzenia przez Trybunał II Instancji, tj. Sąd Metropolitalny w Krakowie. Zawarcie przez pozwaną nowego małżeństwa wymagałoby - po zatwierdzeniu wyroku przez Trybunał II Instancji - zgody właściwego Ordynariusza miejsca, po zasięgnięciu opinii biegłego. 